\title{
ENVIRONMENTAL VARIABLES OF THE SETI GANDAKI RIVER BASIN POKHARA, NEPAL
}

\author{
K. K. Pokharel, K. B. Basnet, T. C. Majupuria and \\ C. B. Baniya
}

Journal of Institute of Science and Technology

Volume 22, Issue 2, January 2018

ISSN: 2469-9062 (print), 2467-9240 (e)

\section{Editors:}

Prof. Dr. Kumar Sapkota

Prof. Dr. Armila Rajbhandari

Assoc. Prof. Dr. Gopi Chandra Kaphle

Mrs. Reshma Tuladhar

JIST, 22 (2): 129-139 (2018)

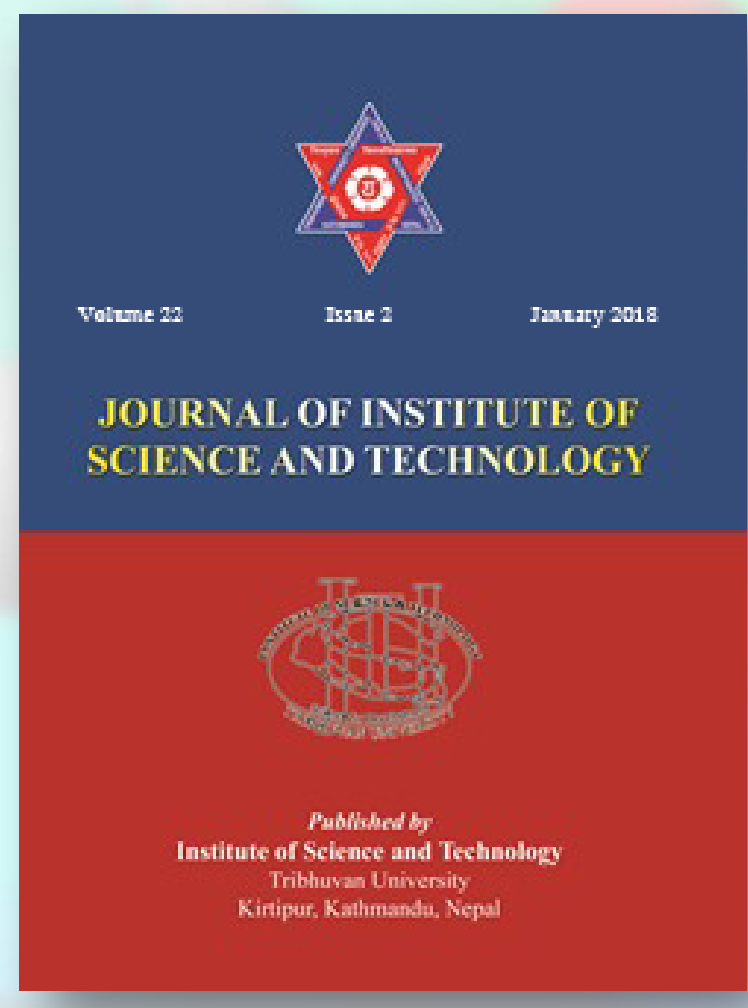

Published by:

Institute of Science and Technology

Tribhuvan University

Kirtipur, Kathmandu, Nepal 


\title{
ENVIRONMENTAL VARIABLES OF THE SETI GANDAKI RIVER BASIN POKHARA, NEPAL
}

\author{
Kishor Kumar Pokharel ${ }^{1 *}$, Khadga Bahadur Basnet ${ }^{2}$, \\ Trilok Chandra Majupuria ${ }^{2}$ and Chitra Bahadur Baniya ${ }^{3}$ \\ ${ }^{I}$ Department of Zoology, Prithvi Narayan Campus, Pokhara \\ ${ }^{2}$ Central Department of Zoology, Tribhuvan University, Kathmandu \\ ${ }^{3}$ Central Department of Botany, Tribhuvan University, Kathmandu \\ "Corresponding E-mail: kishorpokharel82@gmail.com
}

Received: 13 November, 2016; Revised: 12 February, 2017; Accepted: 15 February, 2017

\begin{abstract}
Present paper focuses on the spatio-temporal variations and correlations among the environmental variables of the Seti Gandaki River basin, Pokhara, Nepal. A total of five sites, three along the river and two in tributaries were selected for this study. Water sampling was done fortnightly for environmental variables following standard methods during July 2011 to June 2012. Mean and standard deviation of the environmental variables revealed that the depth $(0.9 \pm 0.3)$, $\mathrm{pH}(8 \pm 0.4)$, total phosphates $\left(\mathrm{PO}_{4}\right)(0.10 \pm$ $0.03)$ and nitrates $\left(\mathrm{NO}_{3}\right)(0.13 \pm 0.04)$ were normally variable among the sites. But the discharge $(40.00 \pm$ $37.00)$, width $(32.30 \pm 13.00)$, turbidity $(81.40 \pm 51.00)$, transparency $(29.10 \pm 15.00)$, conductivity $(166.00$ $\pm 80.00)$, water temperature $(18.00 \pm 4.00)$, dissolved oxygen (DO) $(8.00 \pm 2.00)$, free carbon dioxide $\left(\mathrm{CO}_{2}\right)$ $(7.00 \pm 2.00)$ and total alkalinity $(98.00 \pm 22.00)$ varied among sites equally. Correlation coefficient between the sites and environmental variables revealed that sites were found significantly correlated with water conductivity $\left(\mathrm{r}^{2}=0.6\right)$, DO $\left(\mathrm{r}^{2}=-0.52\right)$, and free $\mathrm{CO}_{2}\left(\mathrm{r}^{2}=0.6\right)$; depth of water with width $\left(\mathrm{r}^{2}=0.94\right)$, discharge $\left(r^{2}=0.96\right)$, turbidity $\left(r^{2}=0.71\right)$, transparency $\left(r^{2}=-0.62\right)$, water temperature $\left(r^{2}=0.60\right), \mathrm{pH}\left(\mathrm{r}^{2}=\right.$ $-0.52)$ and $\mathrm{DO}\left(\mathrm{r}^{2}=-0.48\right)$; water temperature with $\mathrm{pH}\left(\mathrm{r}^{2}=-0.54\right), \mathrm{DO}\left(\mathrm{r}^{2}=-0.79\right)$, free $\mathrm{CO}_{2}\left(\mathrm{r}_{2}=0.69\right)$, total alkalinity $\left(r^{2}=-0.58\right)$, total $\mathrm{PO}_{4}\left(r^{2}=0.54\right)$ and $\mathrm{NO}_{3}\left(r^{2}=0.62\right)$, etc. The enhancement of turbidity, conductivity, free $\mathrm{CO}_{2}$, phosphates and nitrates, while, suppression of transparency, $\mathrm{pH}$ and $\mathrm{DO}$ at the urban site indicated the urban influence.
\end{abstract}

Keywords: Abiotic parameters, Variations, Correlations, Riverine habitat, Nepal Himalayas.

\section{INTRODUCTION}

Freshwater biologists have common opinion on the alteration of aquatic ecosystems, rapid deterioration of water quality, destruction of habitat, and decline in the species diversity, and suggested regular ecological monitoring of waterbodies (Wetzel, 2001; Quist et al., 2004). The spatio-temporal variations of abiotic characteristics such as, DO and $\mathrm{pH}$ are often higher at upstream but lower at urban and downstream reaches; in contrast to free $\mathrm{CO}_{2}$, conductivity, compounds of phosphorus and nitrogen, which were lower at upstream reaches but higher at urban and downstream reaches due to environmental pollution (Osmundson et al., 2002; $\mathrm{Bu}$ et al., 2010). The literature on ecological studies of lotic water-bodies of Nepal is considerable, while that of the Pokhara Valley in particular is much scanty. Shrestha et al. (1979), Swar and Shrestha (1997), Nepal Agriculture Research Council (NARC) (1998-99), Edds et al. (2002) and Kannel et al. (2008) performed studies on various aspects of ecology of water-bodies in Nepal. Works on some aspects of ecology of water-bodies in the Pokhara Valley are those of Hickel (1973), Ferrow (1981-82), John and Dhewajoo (1989), Agriculture Research Center (ARC) Pokhara (2001-02), Gautam et al. (2006) and Pokharel et al. (2010). However, thorough study on those aspects of present water-bodies probably has not yet been performed. Considering their role in aquatic ecosystem, present study aims to focus on the spatio-temporal changes and correlations among the environmental variables of 
the Seti Gandaki River basin in the Pokhara Valley, Nepal.

\section{MATERIALS AND METHODS}

\section{Study area}

Pokhara Valley is lying in the southern flank of Annapurna Himalayan range in Western Nepal, bounded by Mahabharat hills and high Himalayan ranges to the northern side and mid-hills in the eastern, southern and western sides. It is located between $27^{\circ} 50^{\prime}$ and $28^{\circ} 10^{\prime} \mathrm{N}$ latitude and $83^{\circ} 50^{\prime}$ and $84^{0} 50^{\prime} \mathrm{E}$ longitude, altitudes from $540 \mathrm{~m}$ to $1020 \mathrm{~m}$ above sea level (m asl), covering an area of about $200 \mathrm{~km}^{2}$ (Tripathi, 1984-85). Lotic waterbodies running through the valley are the Seti Gandaki River and its tributaries. The river has its origin near the base of the Mount Machhapuchhre $(6,997 \mathrm{~m})$ and the Mount Annapurna IV (7,525 m) and is fed by the glaciers. The total length and the catchment area of the river are nearly $112.6 \mathrm{~km}$ and $600 \mathrm{~km}^{2}$ respectively (Sharma, 1977). The Mardi and the Vijaypur are the major tributaries. These water-bodies constitute Himalayan riverine ecosystems having unique features such as, high velocity, low to moderate temperature, unstable river-bed substrata etc. Five study sites (A to E) were selected representing upstream, urban and downstream sites from the Seti Gandaki River, the Mardi stream and the Vijaypur stream based on accessibility and less human disturbances (Fig. 1).

Site A (Lahachok area in main channel) and Site B (Mardi stream/upstream tributary) each were upstream sites, $11.12 \mathrm{~km}$ from the urban site, had patchy forests, rural settlements and cultivated land in their catchment. Site C (Ramghat area in main channel) was the urban site, about $2 \mathrm{~km}$ east of the Pokhara city center with urban area and cultivated land in the catchment. Site D (Vijaypur stream/downstream tributary) was $8.46 \mathrm{~km}$ downstream from the urban site, had some urban influence, cultivated land, poultry farms and human settlement area in the catchment. Site E (Kotre area) was the downstream site along the main channel, $15.39 \mathrm{~km}$ from urban site, had cultivated land, patchy forests and human settlements in the catchment. The river-bed showed less sand and gravel, but more cobbles and boulders in the upstream sites than in the urban and downstream sites.
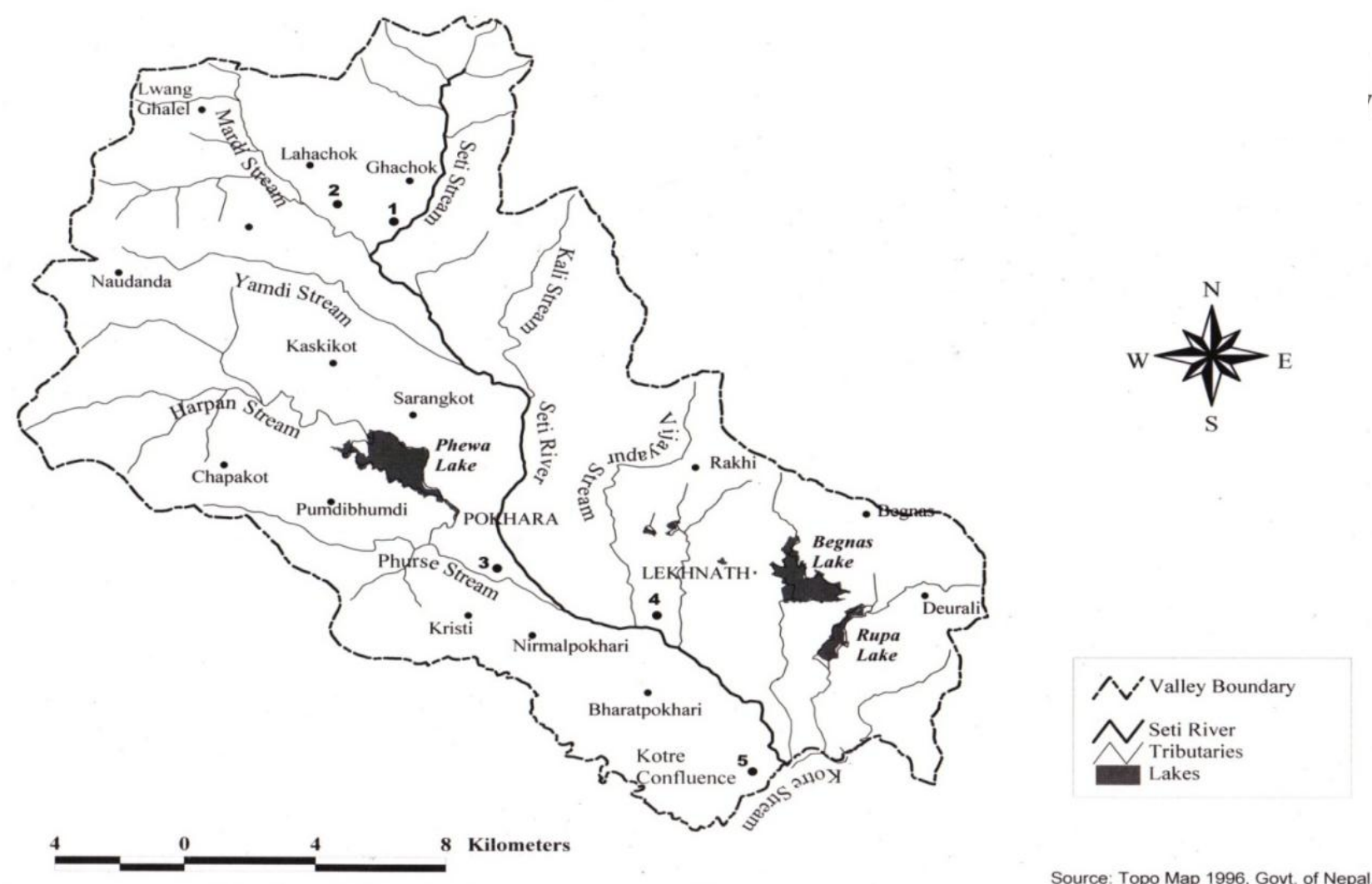

Fig.1. Study area in Pokhara Valley (• Sites 1-5 = Sites A-E). 


\section{Sampling}

Sampling was done fortnightly, three replicates were taken for each environmental variable, and the data were pooled and tabulated as monthly observations. It was performed during July 2011 to June 2012. Water samples were collected and analyzed following the standard methods of Golterman et al. (1978), Trivedy and Goel (1984), Das (1989) and American Public Health Association (APHA1998). The environmental variables such as, depth, width, velocity, turbidity transparency, conductivity, temperature, $\mathrm{pH}, \mathrm{DO}$, $\mathrm{F}-\mathrm{CO}_{2}$ and alkalinity were recorded and determined at the site, while samples for the variables such as, $\mathrm{PO}_{4}$, and $\mathrm{NO}_{3}$ were carried to the laboratory and analyzed as soon possible. Detail on methodology is as follows: depth of water was measured with strong graduated pole dipping straight into the water and touching the bottom at five points from one bank to the other and mean depth was calculated. Width of river was measured by using a graduated tape and extended it from one bank to the other, at five points and mean width was calculated. The velocity of water was measured by 'surface float method'. The discharge or rate of flow of water was calculated by the Leopold et al.'s method (Leopold et al., 1964). Turbidity of water was determined by Hanna Microprocessor Turbidity meter (HI 93703, Portugal) and the readings were expressed in FTU (Formazine Turbidity Unit). Conductivity and Hydrogen ion concentration $(\mathrm{pH})$ were determined by Hanna Water Test (Hanna Instruments- " 4 in one" Portable meter, Portugal) at the site and expressed in the $\mu$ mhos and with a range of 1.0-14.0 and an accuracy of 0.1 respectively. Temperature was recorded using a standard mercury thermometer graduated as $0-50^{\circ}$ $\mathrm{C}$, having a precision of $0.1^{\circ} \mathrm{C}$. Dissolved oxygen was determined by the Winkler's Iodometric Method and expressed as mg/l. Free carbon dioxide and total alkalinity were determined by titrimetric method and expressed as $\mathrm{mg} / \mathrm{l}$. Total phosphate and nitrate were determined following persulphate digestion method and phenol-disulphonic acid method respectively by Spectrophotometer (S106, WPA Linton, Cambridge, UK), and were expressed as $\mathrm{mg} / \mathrm{l}$.

\section{Data analysis}

Pearson correlation coefficient matrixes (Anderson, 2006) among the environmental variables were computed. All data entries were done in MS-Excel and analyses were done by R Version 4.3.1 (R Core Team, 2017).

\section{RESULTS}

\section{Spatio-temporal variations}

The environmental variables generally govern the quality of natural environment of the waterbodies. Mean and standard deviation of the environmental variables included in the study were shown in the Table 1 . The depth of the water-bodies found normally variable among studied sites $(0.9 \pm 0.3)$. This was also true for water $\mathrm{pH}(8 \pm 0.4), \mathrm{T}-\mathrm{PO}_{4}$ and $\mathrm{NO}_{3}$. But the discharge (40 \pm 37$)$, width (32 \pm 13$)$, turbidity $(81.40 \pm 51.00)$, transparency $(29.10 \pm 15.00)$, conductivity ( $166.00 \pm 80.00)$, water temperature $(18.00 \pm 04.00)$, dissolved oxygen (08.00 \pm $02.00)$, free carbon dioxide $(07.00 \pm 02.00)$ and total alkalinity $(98.00 \pm 22.00)$ varied among sites equally.

Table 1: Environmental variables and characters.

\begin{tabular}{|l|l|l|}
\hline \multicolumn{1}{|c|}{ Variable } & \multicolumn{1}{c|}{ Mean } & \multicolumn{1}{c|}{ Standard Deviation } \\
\hline Depth $(\mathrm{m})$ & 00.90 & \pm 00.30 \\
\hline Width $(\mathrm{m})$ & 32.30 & \pm 13.00 \\
\hline Velocity $(\mathrm{m} / \mathrm{s})$ & 01.10 & \pm 00.30 \\
\hline Discharge $\left(\mathrm{m}^{3} / \mathrm{s}\right)$ & 40.00 & \pm 37.00 \\
\hline Turbidity $(\mathrm{FTU})$ & 81.40 & \pm 51.00 \\
\hline Transparency $(\mathrm{cm})$ & 29.10 & \pm 15.00 \\
\hline Conductivity $(\mu \mathrm{mho})$ & 166.00 & \pm 80.00 \\
\hline Temperature-water $\left({ }^{\circ} \mathrm{C}\right)$ & 18.00 & \pm 04.00 \\
\hline pH & 08.00 & \pm 00.40 \\
\hline Dissolved oxygen $(\mathrm{DO})(\mathrm{mg} / \mathrm{l})$ & 08.00 & \pm 02.00 \\
\hline
\end{tabular}




\begin{tabular}{|c|c|c|}
\hline Free carbon dioxide $\left(\mathrm{F}-\mathrm{CO}_{2}\right)(\mathrm{mg} / \mathrm{l})$ & 07.00 & \pm 02.00 \\
\hline Total alkalinity $(\mathrm{TA})(\mathrm{mg} / \mathrm{l})$ & 98.00 & \pm 22.00 \\
\hline Total- phosphate $\left(\mathrm{T}-\mathrm{PO}_{4}\right)(\mathrm{mg} / \mathrm{l})$ & 00.100 & \pm 00.030 \\
\hline Nitrate $\left(\mathrm{NO}_{3}\right)(\mathrm{mg} / \mathrm{l})$ & 00.130 & \pm 00.040 \\
\hline
\end{tabular}

The pattern of spatio-temporal changes in important variables observed during the study period was presented in Figures 2 to 11. Depth of water was higher during summer and autumn seasons in comparison to other seasons, with minimum $(0.51 \mathrm{~m})$ recorded in February at Site B and maximum (1.91m) in August at Site E. Width of river/stream was higher during summer and autumn seasons with minimum $(14.00 \mathrm{~m})$ recorded in February at Site B and maximum $(72.33 \mathrm{~m})$ in August at Site E. Velocity of water was highest $\left(2.00 \mathrm{~ms}^{-1}\right)$ during summer season in August at Site A and declined to its lowest $(0.55$ $\mathrm{ms}^{-1}$ ) during winter in February at Site B. Discharge of water was highest $\left(171.30 \mathrm{~m}^{3} \mathrm{~s}^{-1}\right)$ during summer in August at Site E and with its lowest $\left(3.92 \mathrm{~m}^{3} \mathrm{~s}^{-1}\right)$ during winter in February at Site B.

Transparency of water was highest $(61.50 \mathrm{~cm})$ during winter season in January at Site A and decreased to its lowest $(6.50 \mathrm{~cm})$ during summer in July at Site C. In contrary, the turbidity of water was highest (190.25 FTU) during summer season in July at Site C, with its lowest (7.00 FTU) during winter in January at Site B. The conductivity of water was highest $(297.25 \mu \mathrm{mho})$ during winter in January at Site E and declined to its lowest (38.00 $\mu$ mho) during summer in August at Site A. The water temperature was also highest $\left(23.00^{\circ} \mathrm{C}\right)$ during summer in July at Site E, with its lowest $\left(8.40^{\circ} \mathrm{C}\right)$ during winter in January at Site B.

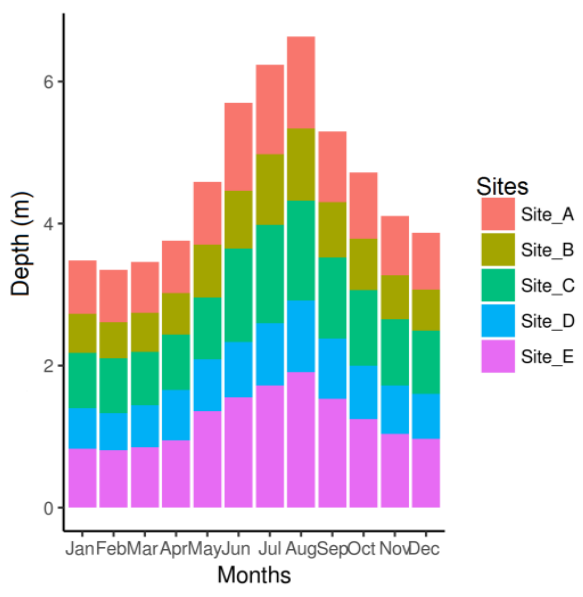

Fig. 2. Monthly sitewise variations in depth.
Hydrogen ion concentration $(\mathrm{pH})$ was highest (8.70) during spring season in March at Site A and decreased to its lowest (6.80) during summer in August at Site C. However, it was higher during autumn and winter seasons. Likewise, dissolved oxygen was highest $\left(12.40 \mathrm{mg} \mathrm{L}^{-1}\right)$ during winter in January at Site A and lowest value $\left(3.44 \mathrm{mgl}^{-1}\right)$ during summer in July at Site D. However, it was higher during spring and autumn seasons. Free carbon dioxide dissolved in water was highest $\left(10.50 \mathrm{mgl}^{-1}\right)$ during summer in July at Site D, and its lowest $\left(3.30 \mathrm{mgl}^{-1}\right)$ recorded during winter in January at Site A. However, it was higher during autumn and spring seasons. Total alkalinity was highest (145.00 $\mathrm{mgl}^{-1}$ ) during winter season in January at Site $\mathrm{C}$ and declined to its minimum $\left(50.00 \mathrm{mgl}^{-1}\right)$ during summer in August at Site B. However, it was higher during spring and autumn seasons.

Total phosphate was highest $\left(0.147 \mathrm{mgl}^{-1}\right)$ during spring season in May at Site $\mathrm{C}$, which declined to its minimum $\left(0.036 \mathrm{mgl}^{-1}\right)$ during winter in January at Site B. However, it was higher during summer and autumn seasons. Nitrate was highest $\left(0.228 \mathrm{mgl}^{-1}\right)$ during spring season in May at Site $\mathrm{C}$, and declined to its minimum $\left(0.052 \mathrm{mgl}^{-1}\right)$ during winter in January at Site B. However, it was also higher during summer and autumn seasons.

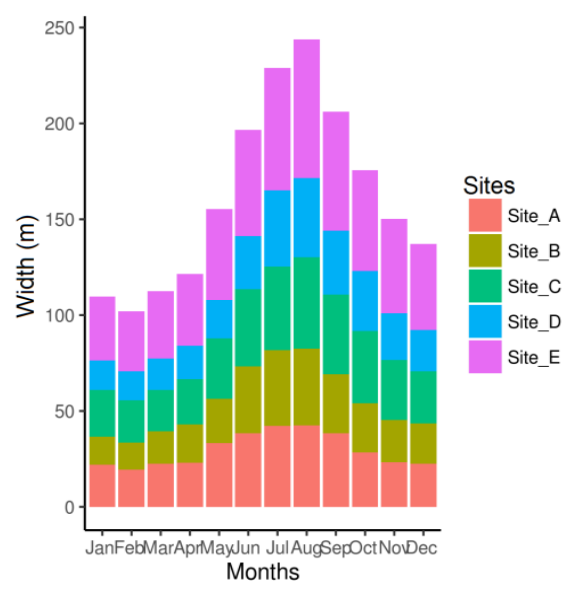

Fig. 3. Monthly sitewise variations in width. 


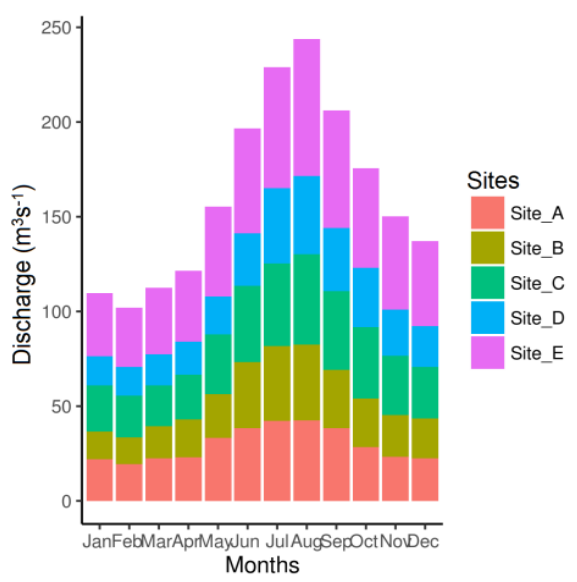

Fig. 4. Monthly sitewise variations in discharge.

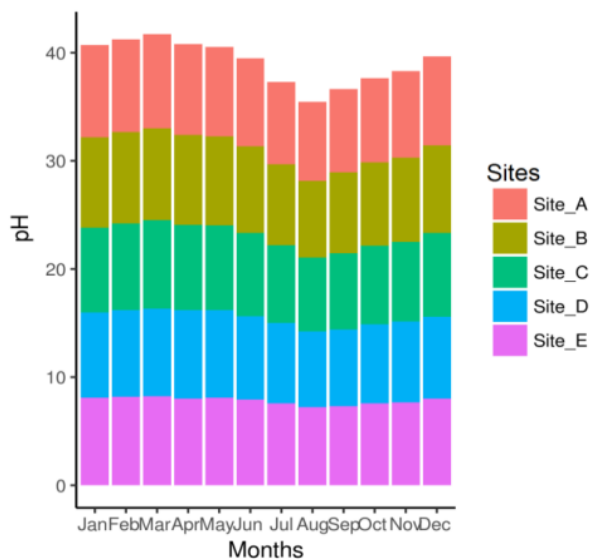

Fig. 6. Monthly site-wise variations in $\mathrm{pH}$.

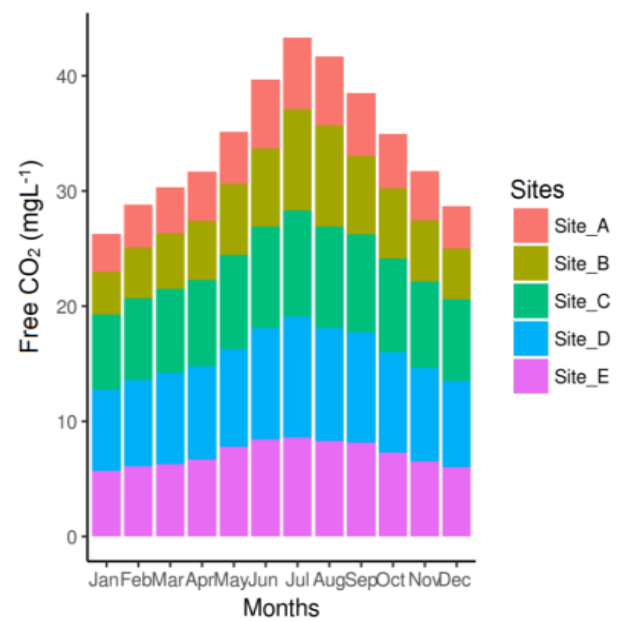

Fig. 8. Monthly site-wise variations in free carbon dioxide.

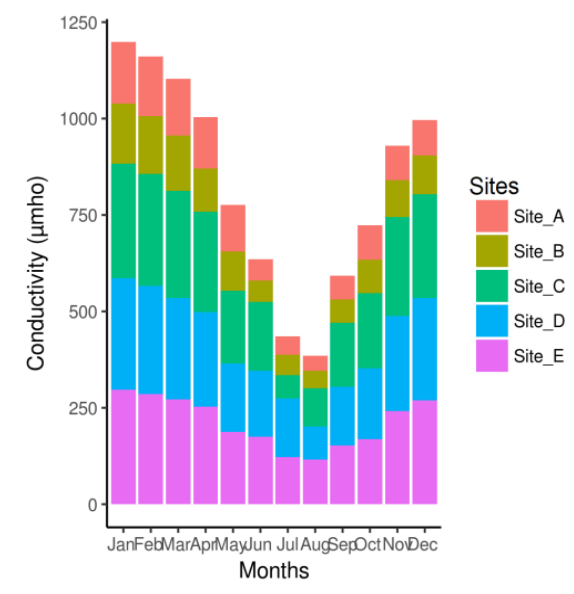

Fig. 5. Monthly sitewise variations in conductivity.

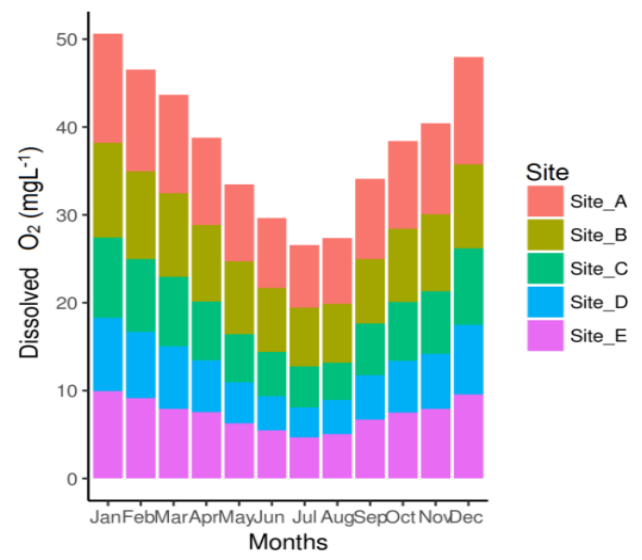

Fig. 7. Monthly site-wise variations in dissolved oxygen.

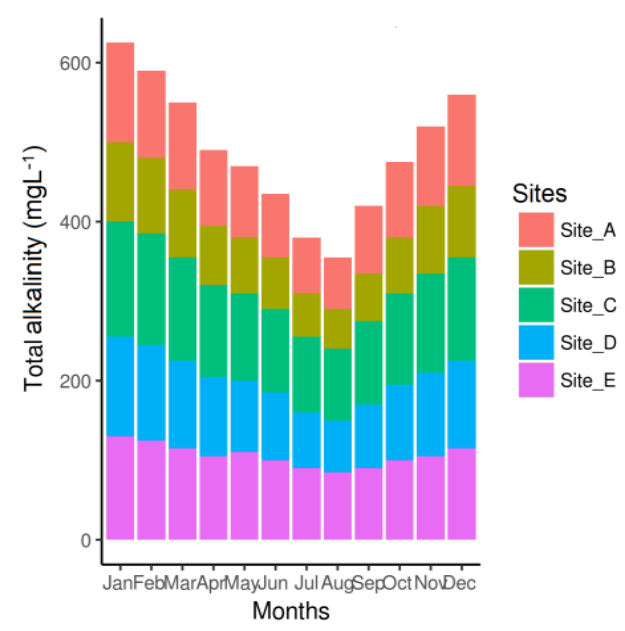

Fig. 9. Monthly site-wise variations in total alkalinity. 


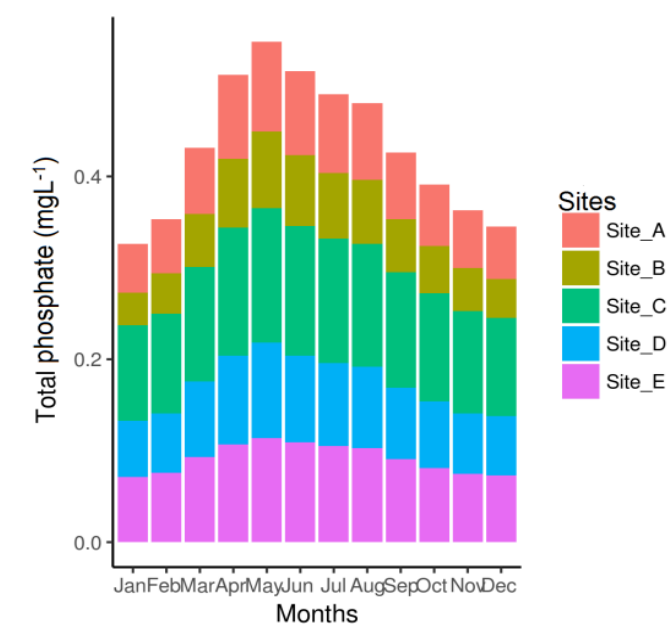

Fig. 10. Monthly site-wise variations in total phosphates.

\section{Correlation}

Correlation coefficient between measured water chemistry and studied sites showed varied results were shown in the Table 2. Site was found significantly correlated with water conductivity $\left(\mathrm{r}^{2}=\right.$ $0.6)$, $\mathrm{DO}\left(\mathrm{r}^{2}=-0.52\right)$, free $\mathrm{CO}_{2}\left(\mathrm{r}^{2}=0.6\right)$; water depth was highly correlated with width $\left.\mathrm{r}^{2}=0.94\right)$, velocity $\left(r^{2}=0.57\right)$, discharge $\left(r^{2}=0.96\right)$, turbidity $\left(r^{2}=0.71\right)$, transparency $\left(\mathrm{r}^{2}=-0.62\right)$, water temperature $\left(\mathrm{r}^{2}=\right.$ $0.60), \mathrm{pH}\left(\mathrm{r}^{2}=-0.52\right)$, DO $\left(\mathrm{r}^{2}=-0.48\right)$; width correlated with discharge $\left(r^{2}=0.91\right)$, turbidity $\left(r^{2}=\right.$ $0.65)$, transparency $\left(\mathrm{r}^{2}=-0.56\right)$, water temperature $\left(\mathrm{r}^{2}=0.61\right), \mathrm{pH}\left(\mathrm{r}^{2}=-0.57\right)$ and $\mathrm{DO}\left(\mathrm{r}^{2}=-0.50\right)$; discharge correlated with turbidity $\left(r^{2}=0.76\right)$, water temperature $\left(\mathrm{r}^{2}=0.63\right), \mathrm{pH}\left(\mathrm{r}^{2}=-0.55\right)$; turbidity correlated with transparency $\left(\mathrm{r}^{2}=-0.88\right)$, water temperature $\left(\mathrm{r}^{2}=0.84\right), \mathrm{pH}\left(\mathrm{r}^{2}=-0.50\right), \mathrm{DO}(\mathrm{r} 2=$ $0.71)$, free $\mathrm{CO}_{2}\left(\mathrm{r}^{2}=0.59\right)$, total $\mathrm{PO}_{4}\left(\mathrm{r}^{2}=0.58\right), \mathrm{NO}_{3}$ $\left(\mathrm{r}^{2}=0.62\right)$; transparency correlated with water temperature $\left(\mathrm{r}^{2}=-0.88\right), \mathrm{DO}\left(\mathrm{r}^{2}=0.77\right)$, free $\mathrm{CO}_{2}(\mathrm{r} 2$ $=-0.64)$, total $\mathrm{PO}_{4}\left(\mathrm{r}^{2}=-0.73\right), \mathrm{NO}_{3}\left(\mathrm{r}^{2}=-0.80\right)$; conductivity correlated with total alkalinity $\left(\mathrm{r}^{2}=\right.$

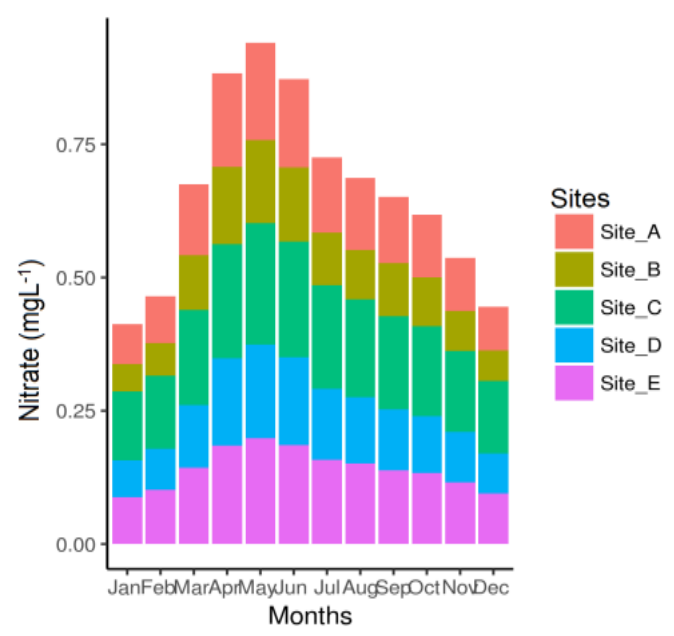

Fig. 11. Monthly site-wise variations in nitrates.

$0.83)$; water temperature correlated with $\mathrm{pH}\left(\mathrm{r}^{2}=-\right.$ $0.54)$, DO $\left(\mathrm{r}^{2}=-0.79\right)$, free $\mathrm{CO}_{2}\left(\mathrm{R}^{2}=0.69\right)$, total alkalinity $\left(\mathrm{r}^{2}=-0.58\right)$, total $\mathrm{PO}_{4}\left(\mathrm{r}^{2}=0.54\right), \mathrm{NO}_{3}\left(\mathrm{r}^{2}=\right.$ $0.62)$; $\mathrm{pH}$ correlated with DO $\left(\mathrm{r}^{2}=0.69\right)$, free $\mathrm{CO}_{2}\left(\mathrm{r}^{2}\right.$ $=0.73)$; $\mathrm{DO}$ with free $\mathrm{CO}_{2}\left(\mathrm{r}^{2}=-0.94\right)$, total $\mathrm{PO}_{4}\left(\mathrm{r}^{2}\right.$ $=-0.60), \mathrm{NO}_{3}\left(\mathrm{r}^{2}=-0.55\right)$; free $\mathrm{CO}_{2}$ correlated with total $\mathrm{PO}_{4}\left(\mathrm{r}^{2}=0.57\right)$ and total $\mathrm{PO}_{4}$ correlated with $\mathrm{NO}_{3}\left(\mathrm{r}^{2}=0.92\right)$. It shows that the values of the variables such as, depth, width, velocity, discharge, turbidity, free carbon dioxide, and water temperature were found to be positively correlated with each other, while negatively with transparency, conductivity, $\mathrm{pH}$, dissolved oxygen, total alkalinity. Likewise, the values of, phosphates, and nitrates were positively correlated with each other, while negatively with transparency and dissolved oxygen during the study period. It can be justified by the fact that the earlier variables were enhanced by seasonal floods during summer and pollution at urban site, while, in contrast the later variables were suppressed due to decrease in transparency there by reducing photosynthetic process and release of oxygen.

Table 2: Correlation coefficient matrix of environmental variables

\begin{tabular}{|l|l|l|l|l|l|l|l|l|l|l|l|l|}
\hline Parameter & \multicolumn{1}{|c|}{ Site } & Month & Dep & Wid & Vel & Disc & Turb & Trans & Cond & A-tem & W-tem & pH \\
\hline Site & 1 & & & & & & & & & & & \\
\hline Month & 0 & 1 & & & & & & & & & & \\
\hline Dep & 0.29 & 0.27 & 1 & & & & & & & & & \\
\hline Wid & 0.42 & 0.35 & $0.94^{\mp}$ & 1 & & & & & & & & \\
\hline Vel & -0.39 & 0.3 & $0.57^{*}$ & $0.50^{*}$ & 1 & & & & & & & \\
\hline Disc & 0.16 & 0.27 & $0.96^{\neq}$ & 0.91 & $0.68^{*}$ & 1 & & & & & & \\
\hline Turb & 0.08 & 0.07 & $0.71^{*}$ & $0.65^{*}$ & $0.70^{*}$ & $0.76^{\gamma}$ & 1 & & & & & \\
\hline Trans & -0.17 & 0.01 & $-0.62^{*}$ & $-0.56^{*}$ & -0.49 & $0.61^{*}$ & $-0.88^{ \pm}$ & 1 & & & & \\
\hline
\end{tabular}




\begin{tabular}{|l|l|l|l|l|l|l|l|l|l|l|l|l|}
\hline Cond & $0.60^{*}$ & -0.32 & -0.29 & -0.25 & $-0.70^{*}$ & -0.44 & -0.44 & 0.29 & 1 & & & \\
\hline A-tem & 0.31 & 0.19 & $0.67^{*}$ & $0.69^{*}$ & 0.49 & $0.67^{*}$ & $0.85^{\gamma}$ & $-0.91^{\neq}$ & -0.37 & 1 & & \\
\hline W-tem & 0.22 & 0.16 & $0.60^{*}$ & $0.61^{*}$ & $0.52^{*}$ & $0.63^{*}$ & $0.84^{\gamma}$ & $-0.88^{\neq}$ & -0.37 & $0.96^{\ddagger}$ & 1 \\
\hline $\mathrm{pH}$ & -0.27 & $-0.57^{*}$ & $-0.52^{*}$ & $-0.57^{*}$ & -0.43 & $-0.55^{*}$ & $-0.50^{*}$ & 0.41 & 0.22 & $-0.53^{*}$ & $-0.54^{*}$ & 1 \\
\hline $\mathrm{DO}$ & $-0.52^{*}$ & -0.19 & $-0.48^{*}$ & $-0.50^{*}$ & -0.22 & -0.47 & $-0.71^{*}$ & $0.77^{\gamma}$ & 0.05 & $-0.83^{\gamma}$ & $-0.79^{\gamma}$ & $0.69^{*}$ \\
\hline F-CO & $0.60^{*}$ & 0.19 & 0.41 & 0.45 & 0.13 & 0.37 & $0.59^{*}$ & $-0.64^{*}$ & 0.12 & $0.71^{*}$ & $0.69^{*}$ & $-0.73^{*}$ \\
\hline T-alk & 0.28 & -0.3 & -0.19 & -0.26 & $-0.53^{*}$ & -0.37 & -0.49 & 0.4 & $0.83^{\gamma}$ & $-0.56^{*}$ & $-0.58^{*}$ & 0.33 \\
\hline T-har & 0.08 & -0.29 & -0.43 & -0.47 & $-0.60^{*}$ & $-0.56^{*}$ & $-0.73^{*}$ & $0.68^{*}$ & $0.72^{*}$ & $-0.81^{\gamma}$ & $-0.82^{\gamma}$ & 0.49 \\
\hline D-Ca & 0.01 & -0.2 & $-0.58^{*}$ & $-0.58^{*}$ & $-0.66^{*}$ & $-0.67^{*}$ & $-0.86^{\neq}$ & $0.81^{\gamma}$ & $0.67^{*}$ & $-0.90^{\neq}$ & $-0.88^{\neq}$ & 0.46 \\
\hline $\mathrm{Mg}$ & 0.15 & 0.01 & $0.68^{*}$ & $0.64^{*}$ & $0.59^{*}$ & $0.69^{*}$ & $0.89^{\neq}$ & $-0.84^{\gamma}$ & -0.4 & $0.85^{\gamma}$ & $0.78^{\gamma}$ & -0.34 \\
\hline $\mathrm{Cl}$ & $0.53^{*}$ & -0.25 & -0.12 & -0.11 & $-0.64^{*}$ & -0.32 & -0.4 & 0.26 & $0.88^{*}$ & 0.36 & -0.4 & 0.26 \\
\hline $\mathrm{O}_{-\mathrm{PO}}$ & 0.36 & 0.02 & 0.49 & 0.38 & 0.12 & 0.34 & $0.51^{*}$ & $-0.68^{*}$ & 0.25 & 0.52 & 0.48 & -0.36 \\
\hline $\mathrm{T}-\mathrm{PO}_{4}$ & 0.29 & -0.06 & $0.51^{*}$ & 0.4 & 0.18 & 0.37 & $0.58^{*}$ & $-0.73^{*}$ & 0.21 & $0.56^{*}$ & $0.54^{*}$ & -0.34 \\
\hline $\mathrm{NH}_{3}$ & 0.37 & -0.33 & 0.36 & 0.25 & -0.07 & 0.2 & 0.44 & $-0.63^{*}$ & 0.38 & 0.42 & 0.38 & -0.08 \\
\hline $\mathrm{NO}_{2}$ & 0.37 & -0.08 & 0.46 & 0.4 & 0.14 & 0.35 & $0.64^{*}$ & $-0.81^{\gamma}$ & 0.14 & 0.7 & $0.64^{*}$ & -0.29 \\
\hline $\mathrm{NO}_{3}$ & 0.16 & -0.08 & 0.49 & 0.39 & 0.25 & 0.37 & $0.62^{*}$ & $-0.80^{\gamma}$ & 0.02 & $0.67^{*}$ & $0.62^{*}$ & -0.17 \\
\hline $\mathrm{Sil}$ & $0.67^{*}$ & 0.05 & 0.43 & 0.41 & -0.15 & 0.26 & 0.28 & -0.4 & $0.56^{*}$ & 0.32 & 0.27 & -0.47 \\
\hline
\end{tabular}

Table 2: (contd.)

\begin{tabular}{|c|c|c|c|c|c|c|c|c|c|c|c|c|}
\hline DO & $\mathrm{F}-\mathrm{CO}_{2}$ & T-alk & T-har & D-Ca & Mg & Cl & O-PO ${ }_{4}$ & $\mathrm{~T}-\mathrm{PO}_{4}$ & $\mathbf{N H}_{3}$ & $\mathrm{NO}_{2}$ & $\mathrm{NO}_{3}$ & Sil \\
\hline & & & & & & & & & & & & \\
\hline & & & & & & & & & & & & \\
\hline 1 & & & & & & & & & & & & \\
\hline$-0.94^{\neq}$ & 1 & & & & & & & & & & & \\
\hline 0.33 & -0.18 & 1 & & & & & & & & & & \\
\hline $0.61 *$ & -0.47 & $0.89^{\neq}$ & 1 & & & & & & & & & \\
\hline $0.66^{*}$ & $-0.51 *$ & $0.81^{\gamma}$ & $0.95^{\neq}$ & 1 & & & & & & & & \\
\hline$-0.62 *$ & $0.50 *$ & -0.48 & $-0.65 *$ & $-0.86^{\neq}$ & 1 & & & & & & & \\
\hline 0.15 & -0.03 & $0.88^{\neq}$ & $0.77^{\gamma}$ & $0.66 *$ & -0.32 & 1 & & & & & & \\
\hline$-0.61 *$ & $0.59 *$ & 0.26 & -0.06 & -0.24 & 0.49 & 0.36 & 1 & & & & & \\
\hline$-0.60 *$ & $0.57^{*}$ & 0.22 & -0.12 & -0.31 & $0.56^{*}$ & 0.32 & $0.95^{\neq}$ & 1 & & & & \\
\hline-0.48 & 0.47 & 0.36 & 0.06 & -0.16 & 0.49 & 0.48 & $0.86^{\neq}$ & $0.92^{\neq}$ & 1 & & & \\
\hline$-0.71 *$ & $0.66^{*}$ & 0.02 & -0.29 & -0.48 & $0.69 *$ & 0.2 & $0.88^{\neq}$ & $0.92^{\neq}$ & $0.89^{\neq}$ & 1 & & \\
\hline$-0.55^{*}$ & 0.43 & 0.03 & -0.29 & -0.46 & $0.65^{*}$ & 0.17 & $0.85^{\neq}$ & $0.92^{\neq}$ & $0.85^{\neq}$ & $0.90 *$ & 1 & \\
\hline$-0.57 *$ & $0.66^{*}$ & \begin{tabular}{|l|}
0.48 \\
\end{tabular} & 0.17 & 0.03 & 0.24 & $0.61^{*}$ & $0.84^{\gamma}$ & $0.81^{\gamma}$ & $0.78^{\gamma}$ & $0.70^{*}$ & $0.58 *$ & 1 \\
\hline
\end{tabular}

Abbreviations: Dep $=$ Depth, Wid $=$ Width, Vel $=$ Velocity, Disc $=$ Discharge, Turb $=$ Turbidity, Trans $=$ Transparency, Cond $=$ Conductivity, A-tem $=$ Air-Temperature, $W$-tem $=$ Water-temperature, $D O=$ Disolvedoxygen, $\mathrm{F}-\mathrm{CO}_{2}=$ Free Carbon dioxide, $T$-alk $=$ Total alkalinity, $T$-har $=$ Total hardness, $\mathrm{D}$-Ca $=$ Dissolved calcium, $\mathrm{Mg}=$ Magnesium, $\mathrm{Cl}=$ Chloride, $\mathrm{O}-\mathrm{PO}_{4}=$ Ortho-phosphate, $\mathrm{T}-\mathrm{PO}_{4}=$ Total phosphate, $\mathrm{NH}_{3}=\mathrm{Ammonia}$, $\mathrm{NO}_{2}=$ Nitrite, $\mathrm{NO}_{3}=$ Nitrate and Sil $=$ Silicates; $*$ value indicates $p$-value $\leq 0.05$ at $95 \%$ confidence interval.

\section{DISCUSSION}

\section{Spatio-temporal variations}

Higher turbidity and lower transparency values were observed at urban sites and during summer season than at other sites and seasons in the present study, which could be attributed to the prevailing monsoonal climatic conditions and urban influence. Similar results have been reported in middle-hill 
streams, western Nepal (Collins \& Jenkins, 1996) and in River Ramganga, Uttaranchal, India (Pathani \& Upadhyaya, 2006). Lower values of conductivity at the upstream sites and during summer season in the present study could be due to the low flow and dilution of ionic constituents by the rain water, and higher values at urban sites and during winter season due to direct disposal of agricultural and urban wastes into the water; and high concentration of the ionic constituents respectively. Similar variations were reported from the Narayani River, Central Nepal (Sah et al., 2000) and the Manahara River, Nepal (Bajracharya \& Tamrakar, 2007). Higher temperature and free carbon dioxide values during summer season and lower during winter respectively were observed in the present study, which could be related to seasonal climatic conditions, decomposition of organic substances and release of free carbon dioxide, and increased photosynthesis during winter and decline during summer season respectively. Similar variations were mentioned from the Beas Drainage system, western Himalayas, India (Dhanze et al., 1998) and the River Ramganga, India (Pathani \& Upadhyaya, 2006). There was a decline in values of $\mathrm{pH}$ and dissolved oxygen at urban sites and during summer season than at other sites and seasons respectively in the present work, which could be attributed to the influence of increased organic and inorganic load and high turbidity due to urban and agricultural wastes at urban sites; and to the increased transparency and photosynthetic activity during winter and spring seasons; and increased turbidity and decreased photosynthetic activity during summer season. Similar variations were recorded in the Narayani River Nepal (Edds et al., 2002) and the Maroon River, Iran (Tabari et al., 2011).

Higher total alkalinity, values were recorded at urban sites receiving wastes from various sources and during winter season, and lower at other sites and during summer season respectively in the present study, which could be related to the direct disposal of wastes and to increasing concentration of salts, low free carbon dioxide as well as higher $\mathrm{pH}$ values during winter; and to heavy rainfall resulting in dilution of ionic contents, during summer season. Similar variations were reported in Mid-hill streams, Nepal (Collins \& Jenkins, 1996) and in the Maroon River Iran (Tabari et al., 2011). Higher values of phosphates and, nitrates at the urban sites and during summer season in the present study could be attributed to the disposal of urban wastes at the urban site; and to the floodwater containing allochthonous substances from the catchment during summer season. Their lower values during winter could be due to high content of bound organic phosphates and to the only autochthonous production of nitrogen compounds respectively. Similar spatio-temporal trend in those variables were mentioned in the Ramganga River, India (Pathani \& Upadhyaya, 2006) and in the Bagmati River, Nepal (Kannel et al., 2008).

\section{Correlation}

The water temperature exhibited direct relationship with depth, width and discharge, while an inverse relationship with transparency, dissolved oxygen, $\mathrm{pH}$ and total alkalinity in the present study, which could be attributed to the light penetration, reaching deeper when the water is more transparent, enhancing the process of photosynthesis releasing more oxygen. Similar relationship was observed by Pathani and Upadhyaya (2006) in the River Ramganga, India and Pejman et al. (2009) in the Haraz River basin, Iran. Free Carbon dioxide had negative correlation with dissolved, $\mathrm{pH}$, transparency and total alkalinity, while positive correlation with temperature, turbidity and discharge in the present study, which can be related to the decomposition of accumulated organic substances and the respiratory processes of aquatic biota accelerated by the higher temperatures accompanied with higher turbidity and lower transparency and higher discharge, enhancing the production of free carbon dioxide and consumption of available dissolved oxygen, limited by the retardation of photosynthetic process inside water. Similar, correlations were mentioned by Martin and Haniffa (2003) in the South Indian River Tamiraparani and Pathani and Upadhyaya (2006) in the River Ramganga, India.

Hydrogen ion concentration $(\mathrm{pH})$ showed direct relationship with dissolved oxygen, transparency, and alkalinity, while inverse relationship with discharge, turbidity, temperature, and free carbon dioxide in the present study, which could be due to the fact that higher temperature favored increase in free carbon dioxide accompanied with higher discharge and turbidity, while increased transparency favored photosynthetic processes thereby evolving more dissolved oxygen and thus increasing alkalinity and hardness of water. Similar findings were reported by Pathani and Updhayaya (2006) in the Ramganga River, India, and Tabari et al. (2011) in the Maroon River, Iran. A direct relationship of total alkalinity with $\mathrm{pH}$, conductivity 
and transparency, dissolved while inverse relationship with temperature and turbidity were observed in the present study, which can be related to transparent alkaline waters with abundant ionic constituents favoring higher $\mathrm{pH}$ and conductivity; while turbid waters with high discharge and velocity during higher temperature conditions diluted the ionic constituents due to higher precipitation and run-off. Similar relationships were mentioned by Munshi and Singh (1991), and Khanna (1993) in the Ganga River, India.

Total phosphate showed direct relationship with , turbidity, temperature, free carbon dioxide and nitrates in the present study, which could be related to the availability of phosphorus in limited quantities in natural waters with higher transparency and higher concentrations of dissolved oxygen; while during higher temperature conditions in urban areas increased turbidity due to higher precipitation and surface run-off along with allochthonous substances, and higher quantities of nitrogen compounds and silicates. Similar relationships were mentioned by Tyagi et al. (2003) and Kannel et al. (2008) in the River Kshipra, India and in the Urban Corridor (the Bagmati River), Nepal, respectively. A direct relationship of nitrates with turbidity, and temperature, while inverse relationship with transparency and dissolved oxygen, were observed in the present study, which could be related to high turbidity due to high precipitations and surface run-off from the catchment during rainy season or due to direct disposal of agricultural and urban wastes containing high quantities of nitrogen and phosphorus compounds. Similar relationships were reported by Pathani and Upadhyaya (2006) and Kannel et al. (2008) in the Ramganga River, India and in the Urban River Corridor (the Bagmati), Nepal, respectively.

The values of the variables such as, turbidity, conductivity, total alkalinity, phosphates and nitrates were slightly reduced at the downstream site, when compared with the urban site in the present study. This reduction in concentration of urban influenced variables can be related to the self purification of the river water during its course and also to the entry of the less impacted water of the minor tributary the Kotre creek (a perennial creek) into the river, above the post-urban (downstream) sampling site in the main channel.

\section{CONCLUSION}

The entrance of urban wastes into the river enhanced the concentrations of the variables, such as, turbidity, conductivity, free carbon dioxide, alkalinity, phosphates and nitrates; whereas, suppressed the concentrations of the variables, transparency, $\mathrm{pH}$ and dissolved oxygen. Temporal pattern exhibited rise and fall of the variables transparency, $\mathrm{pH}$, dissolved oxygen and alkalinity during winter and summer seasons respectively; where as vice versa shown by the variables, turbidity, free carbon dioxide phosphates and nitrates. The above pattern clearly showed that the former variables were directly correlated with each other, while inversely correlated with the latter ones. The spatio-temporal trend of environmental variables and their correlations observed in the present study agree with the result of previous studies on Nepalese rivers.

\section{ACKNOWLEDGEMENTS}

The authors are grateful to Dean's Office, Institute of Science and Technology, Tribhuvan University, for approval to conduct the present study. Similarly, they are thankful to Mr. R. G. Dhewajoo, Head of Department of Zoology, Prithvi Narayan Campus (PNC), Pokhara, for providing the laboratory facilities. Thanks are also due to Mr. B.R. Pahari, Senior Lab Assistant, PNC and Mr. N.P. Adhikari, Bhalam, Pokhara, for assistance in the field and laboratory works.

\section{REFERENCES}

Agriculture Research Center (ARC) (2001-02). Annual report. Agriculture Research Center (ARC-Fisheries), Pokhara, Nepal. pp.74.

Anderson, T. W. (2006). An introduction to multivariate statistical analysis. John Wiley and Sons, New Jersey, USA, pp. 721.

APHA/AWWA/WEF (1998). Standard methods for the examination of water and wastewater $\left(20^{\text {th }}\right.$ edition). American Public Health Association (APHA), American Water-works Association (AWWA) and Water Environment Federation (WEF), Washington DC, USA. pp. 10-157.

Bajracharya, R. and Tamrakar, N. K. (2007). Environmental status of the Manahara River, Kathmandu, Nepal. Bulletin of the Department of Geology, 10: 21-32.

Baran, E. and Warry, F. (2008). Simple data analysis for biologists. World Fish Center and Fisheries Administration, Phnom Penh, Campuchia, pp. 67.

Bu, H.; Tan, X.; Li, S. and Zhang, Q. (2010). Temporal and spatial variations of water 
quality in the Jinshui River of the South Qinling Mountains, China. Ecotoxicology and Environmental Safety, 73 (5): 907-913.

Collins, R. and Jenkins, A. (1996). The impact of agricultural land use on stream chemistry in the Middle-Hills of the Himalayas, Nepal. Journal of Hydrology, 185 (1-4): 71-86.

Das, S. M. (1989). Aquatic pollution and fisheries in India. In: R. D. Khulbe (ed) Perspectives in aquatic ecology. Papyrus Publishing House, New Delhi, India, pp. 43-49.

Edds, D. R.; Gillette, D. P.; Maskey, T. M. and Mahato, M. (2002). Hot-soda process paper mill effluent effects on fishes and macroinvertebrates in the Narayani River, Nepal. Journal of Freshwater Ecology, 17 (4): 543 554.

Ferrow, W. (1981-82). Limnology of Pokhara Valley lakes (Himalayan Region, Nepal) and its implications for fishery and fish culture. Journal of Nepal Center, Kathmandu, 5 (6): 27-52.

Gautam, G.; Shrestha, J. and Gurung, T. B. (2006). Fish diversity and other aquatic life resources of the Lake Rupa, Pokhara, Western Nepal. Proceedings of fourth national conference on science and technology. Nepal Academy of Science and Technology (NAST), Lalitpur, Nepal, 1: 281-295.

Golterman, H. L.; Clymo, R. S. and Ohnstad, M. (1978). Methods for physical and chemical analysis of freshwaters. IBP Handbook No. 8. Blackwell Scientific Publishers, Oxford, UK, pp. 215.

Hickel, B. (1973). Limnological investigations in lakes of Pokhara Valley, Nepal. International Review of Hydrobiology, 58: 659-672.

John A. and Dhewajoo, R. G. (1989). Effect of ecological parameters on fishes of Pokhara Valley. Royal Nepal Academy of Science and Technology (RONAST), Kathmandu, Nepal, pp.39.

Kannel, P. R.; Lee, S. and Lee, Y. S. (2008). Assessment of spatial-temporal patterns of surface and ground-water quality and factors influencing management strategy of groundwater system in an urban river corridor of Nepal. Journal of Environmental Management, 86 (4): 595-604.

Khanna, D. R. (1993). Ecology and pollution of Ganga River. Ashish Publishing House, New Delhi, India, pp. 241.
Leopold, L. B.; Wolman, M. G. and Miller, J. P. (1964). Fluvial processes in geomorphology. W. H. Freeman, San Francisco, USA, pp. 522.

Martin, P. and Haniffa, M. A. (2003). Water quality profile in the South Indian River, Tamiraparani. Indian Journal of Environmental Protection, 23 (3): 286-292.

Munshi, J. S. D. and Singh, D. K. (1991). Physicochemical profile of the River Ganga at Kahalgaon, Bihar, India. In: B. Gopal and B. Asthana (eds) Aquatic Science in India. Indian Association of Limnology and Oceanography, New Delhi, India, pp. 83-92.

Nepal Agriculture Research Council (1998-99). Annual report. Nepal Agriculture Research Council (NARC), Lalitpur, Nepal, pp. 120.

Osmundson, D. B.; Ryel, R. J.; Lamarra, V. L. and Pitlick, J. (2002). Flow-sediment-biota relations: Implications for river regulation effects on native fish abundance, Ecological Applications, 12 (6): 1719-1739.

Pathani, S. S. and Upadhyaya, K. K. (2006). An inventory of zooplankton, zoo benthos and fish fauna in the River Ramganga (W) of Uttaranchal, India. Envis Bulletin: Himalayan Ecology, 14 (2): 37-46.

Pejman, A. H.; Bidhendi, G. R. N.; Karbassi, A. R.; Mehrdadi, N. and Bidhendi, M. E. (2009). Evaluation of spatial and seasonal variation in surface water quality using multivariate statistical techniques. International Journal of Environment Science and Technology, 6 (3): 467-476.

Pokharel K. K.; Timilsina, G.; Bastola, S. C. and Gurung, S. (2010). Studies on fisheries resources, zoobenthos, some abiotic parameters and socioeconomic aspects of fishermen involved in lakes of Pokhara Valley, Nepal. Nepal Academy of Science and Technology (NAST), Lalitpur, Nepal, pp. 90.

Quist, M. C.; Hubert, W. A. and Isaak, D. J. (2004). Fish assemblage structure and relations with environmental conditions in a Rocky Mountain Watershed. Canadian Journal of Zoology, 82 (10):1554-1565.

R. Cor Team (2017). R: A language and environment for statistical computing. $\mathrm{R}$ Foundation for Statistical Computing, Vienna, Austria. URL https://www.Rproject.org/. 
Sah, J. P.; Shah, S. K.; Acharya, P.; Pant, D. and Lance, V. A. (2000). Assessment of water pollution in the Narayani River, Nepal. International Journal of Ecology and Environmental Sciences, 26: 235-252.

Sharma, C. K. (1977). River systems of Nepal. Ms. Sangeeta Sharma, Kathmandu, Nepal, pp. 211.

Shrestha, S. B.; Shrestha, T. K. and Pradhan, B. R. (1979). Report on the study of aquatic ecology and the potential of fisheries development in Bagmati River Project. German Technical Cooperation (GTZ), Kathmandu, Nepal, pp. 70.

Swar, D. B. and Shrestha, J. (1997). Human impact on aquatic ecosystems and native fishes of Nepal. In: Proceedings of the national symposium on the role of fisheries and aquaculture in the economic development of rural Nepal. Nepal Fisheries Society (NEFIS), Kathmandu, Nepal, pp. 35-46.
Tabari, H.; Marofi, S. and Ahmadi, M. (2011). Long-term variations of water quality parameters in the Maroon River, Iran. Environmental Monitoring and Assessment, 177 (1-4): 273.

Tripathi, M. P. (1984-85). Ecology of Pokhara Valley. In: TC Majupuria (ed) Nepal nature's paradise. White Lotus Company, Bangkok, Thailand, pp. 438-452.

Trivedy, R. K. and Goel, P. K. (1984). Chemical and biological methods for water and pollution studies. Environmental Publications, Karad, India, pp. 247.

Tyagi, A.; Sharma, M. K. and Bhatia, K. K. S. (2003). The study of temporal and spatial trends of water quality of the River Kshipra using water quality index (WQI). Indian Journal of Environmental Health, 45 (1):15-20.

Wetzel, R. G. (2001). Limnology: lake and river ecosystems. Academic Press, Inc., SanDiego, USA, pp.1006. 